DE DE GRUYTER OPEN
Research Article

(C) 2018 SH. Arba

This is an open access article licensed under the Creative Commons Attribution-NonCommercial-NoDerivs License (http://creativecommons.org/licenses/by-nc-nd/3.0/).

\title{
Recognition and Reinforcement of Customary Law Community Association and their Rights over Land and Forest in West Nusa Tenggara Province
}

\author{
Dr. Arba, SH., M. Hum \\ Lecturer of Faculty of Law, \\ Mataram University, Indonesia
}

Doi: $10.2478 / m j s s-2018-0080$

\begin{abstract}
This study aims to analyze recognition and reinforcement of customary law community association and their rights over land and forest in West Nusa Tenggara Province because in this region there are still numerous customary law community associations and their jurisdictions that are always owned, controlled, and done for generations. This study is categorized as a normative study that refers to applicable norms and legal concepts (Indonesian positive law) and reality based on the results of the study. The approaches implemented in the study are legislation approach, conceptual approach, and historical approach. This study was conducted by listing the norms of positive law and then confronting the reality which occurs in the society. It can be concluded that the recognition and reinforcement of the right of customary law community over land and forests in the Constitution and legislation is clear and decisive, however the implementation of recognition and reinforcement of customary law community association and their rights in West Nusa Tenggara Province has not been implemented by the government.
\end{abstract}

Keywords: recognition, reinforcement, indigenous people rights

\section{Introduction}

The association of customary law community has existed and spread throughout the archipelago since ancient times until today. Each of these customary law community associations have territories, citizens, customary authorities, customary values or norms, and also assets belonging to fellowship such as agricultural land, estate, forest land, water territory, and others, all of which are controlled, regulated, managed, and used jointly and continuously by the association of customary law community. The existence of customary law community associations with their legal norms and their assets have been recognized and regulated in the Constitution and legislation, but have not been applied properly in West Nusa Tenggara Province. This is due to the absence and ignorance of will of the local government to recognize and reinforce the position of customary law community and their rights.

As the result, various conflicts of interest raise either vertical conflict of interest, the conflict between customary law communities and government, and horizontal conflict of interest, the conflict between customary law community associations and a private company which obtains government clearance as happened in Dodorinti Sumbawa, at Lambu Sape and Pela Parado in Bima several years ago, and other conflicts. The impact of the conflict raises disharmony between governmental institutions and community groups and disharmony between community groups and private legal entities (investors) that result in the difficulty of the investors to continue their operations. 


\section{Statement of the Problem}

a. How is the law for the recognition and reinforcement of customary law communities and their rights arranged in the positive law of Indonesia?

b. How are the recognition and reinforcement customary law community associations and their rights implemented by the local government in West Nusa Tenggara?

\section{Method of Study}

This study is a normative legal study, which is based on norms, values, legal principles, legal concepts, legal opinions, and research results. Therefore, the methods used involve:

\section{a. Approaches}

Considering that this is a normative legal study, the approaches used are normative approach which includes statute approach, conceptual approach, and analytical approach.

b. Source of legal material

Legal material is obtained through library research which consists of primary legal materials in the form of Laws, Government Regulations, Presidential Regulations, Regional Regulations, and others; secondary legal materials in the form of concepts, expert opinions, and research results; and tertiary legal materials in the form of language dictionaries and legal dictionaries (Soekanto, 1984).

c. Legal material collection technique

The collection of legal materials is conducted by reviewing and analyzing the literature materials, that is examining the laws and regulations as well as books, and the results of prior research related to this legal issue.

d. Methods of analyzing legal material

The method used is descriptive normative, that is the analysis of legal materials by making legal interpretations, either authentic interpretation, grammatical interpretation, or systematic interpretation.

\section{Discussion}

\subsection{Legal arrangements on the recognition and reinforcement of the existence of customary law communities and their rights in the positive law of Indonesia}

\subsubsection{Conception of Customary Law Community Association}

The conception of customary law community association can be found as follows:

Kusumadi Pujosewojo defined legal community as a society that establishes, is bound by, and abides their own law. Whereas customary law community is a society that arises spontaneously in certain areas, whose establishment is not established or commanded by the higher authorities or other rulers with a great sense of solidarity among the members, who regard non-members as outsiders and use their territory as a source of wealth that can only be fully utilized by the members (Soemardjono, 2001).

Boedi Harsono said, "Customary law community with various names in accordance with their respective regional languages is a group of people bounded by their customary legal order as citizens with a legal partnership because of the unity of residence or on the basis of descent equality" (Harsono, 2002).

Legal communities have a sovereign over their territory (tanah ulayat) and they, through the leader of tribe, also have full authority to organize and manage relationship between the people and the nature (Bakri, 2007).

Criteria for the existence of customary law people are:

1. The community is still in the form of familiar community (rechtsgemeenschap) and resides within the territory of customary law concerned;

2. An institution is in the form of traditional ruling (Traditional Institutional Structure) that is still 
functioning;

3. It has a clear customary law territory limits recognized/agreed by the community and among customary law community;

4. There are customary laws relating to forests which are still adhered to;

5. The communities still carry out the utilization and collection of forest products in the surrounding for the fulfillment of daily life and/or the existence of religious relations and community relations with customary forests; and

6. Communities in and around the forest are entitled to compensation for the loss of access to the surrounding forests as employment to meet their living needs due to the establishment of forest area. In this case, everyone is entitled to compensation for the loss of rights to their land as a result of the establishment of forest areas.

The experts of customary law argued that the characteristics of customary law People (adatrechtsgemenschap) are:

1. having an organized human unity;

2. staying in a certain area;

3. having rulers;

4. having material and immaterial wealth;

5. having a value and trust system; and

6. Having their own legal order.

Based on the characteristics mentioned above, one of the examples in the area of West Nusa Tenggara that still exists to date based on the results of research is located in Bayan District, North Lombok. Applying the principles of democracy, the community digs the spirit of community life in collective leadership system. The non-single authority is held by the village head as a part of collective leadership, known as wet tu telu (wet $=$ territory, $t u=$ person $=t e l u=$ three) or each territory has its own leader namely: wet agama, wet adat istiadat, and wet pemerintah. Wet agama is led by kiai, bikku, or pedanda as the ruler of religious norm, wet adat istiadat is led by a mangku (apparatus) and the members of each mangku, like mangkubumi (waters), mangku alas (forest environment), and others. The role of mangku acts as the formulator and determinant of awig-awig, the giving of customary sanction by the leader of traditional ritual event. Wet pemerintahan is led by pamusungan (village head, meaning top chief). The leadership of wet tu telu was done in the Dutch colonial era and the old order before it was formalized by Law No. 5/1974 and Law N0 5/1979 on village administration.

\subsubsection{Conception of Customary Rights}

The conception of hak ulayat (customary right) is proposed by the following legal experts. Boedi Harsono said, "Hak ulayat is a series of powers and obligations of a particular customary law community over a certain territory that becomes their ulayat, as "lebensraum" of its citizens to take advantage of natural resources, including land, that exist in the region" (Harsono, 2002).

Maria S.W. Sumardjono said, "In general, the understanding of hak ulayat primarily concerns on the legal relationship between customary law community and their land in their territory" (Sumardjono, 2008).

The definition of customary rights herein is a communalistic trait that points to the common right by members of the customary law community over a particular land. In practice, the group may be a territorial customary law community (village, clan, forest) or genealogic customary law community, such as tribe. The citizens as members of the group have the right to control and use some of the common ground to meet their personal and family needs, but there is no obligation to take over and use them collectively.

The subject of hak ulayat holders is the customary law community concerned, consisting of the citizens. Therefore, the subject of hak ulayat is not individual and not the leader of tribe. On the other hand, the object of hak ulayat is the area existing in the customary law association which becomes the authority of the customary law community association. Various customary rights that exist in Indonesia include: "hak pertuanan" in Ambon, "panyapeto" in Kalimantan, "wewengkon" in Jawa, "Prabumian" in Bali, "Tanah Paer" in Lombok, and "Ulayat" in Minangkabau (Arba, 2015). 
Boedi Harsono argued that hak ulayat over land can be ascertained based on the fact that:

1. There is still a group of people as citizens of a particular customary law community association, that becomes a customary law society;

2. There is still a territory which becomes ulayat of the customary law community, which is realized as the land belongs to its citizens as their "lebensraum"; and

3. There is still a customary ruler who is in fact recognized by the members of the customary law community, performing daily activities as implementers of hak ulayat (Harsono, 2002).

The criteria determining the existence of hak ulayat, according to Sumardjono (2008), should be seen from 3 (three) things:

1. The existence of customary law communities that fulfill certain characteristics as subject of hak ulayat;

2. The existence of land/territory with certain limits as lebensraum which is the object of hak ulayat; and

3. The existence of the authority of customary law community to perform certain actions.

4.1.3 Legal arrangements on the recognition and reinforcement of customary law community associations and their rights

Legal arrangements on the recognition of the existence of hak ulayat of customary law communities and their rights are regulated in the Constitution (the 1945 Constitution) as well as various laws and regulations.

UUD 45 (amendment) Article $18 \mathrm{~b}$ determines: State recognizes and respects the unity of customary law people along with their traditional rights as long as they are alive and in accordance with the development of society and the principles of the Unitary State of the Republic of Indonesia laid down in law.

Law No. 5 of 1960 on the Agrarian Basic Regulations has clearly defined the recognition and reinforcement of customary law community rights as set forth below:

1. Article 2 Paragraph (4) determines: The implementation of the right to control of the State may be authorized to the Indigenous Territories and customary law communities, insofar as it still exists, is merely necessary, and does not contrary to the national interest in accordance with the provisions of the Government regulation.

2. Article 3 determines: Bearing in mind the provisions of Articles 1 and 2, the implementation of customary rights and similar rights from customary law communities, to the extent that in reality they still exist, shall be such as to be in accordance with the national and state interests based on the unity of the nation and should not conflict with other higher laws and regulations.

3. Article 56 determines: As long as the Law on property rights as mentioned in article 50 paragraph 1 has not yet been established, the prevailing provisions shall be the provisions of local customary law and other regulations on land rights which authorize as or similar to those referred to in article 20, provided that it is not inconsistent with the spirit and provisions of this Act.

Further implementation of the provisions, the government issued the Regulation of the Minister of Agrarian Affairs Number 5 of 1999 on the Guidelines for the Settlement of Customary Right Dispute. Article 1 explains that customary rights are the authority which, according to customary law, belongs to certain customary law community that becomes the environment of its citizens to benefit from natural resources, including land within the territory for survival and livelihood.

Accordingly, the recognition of customary law community rights and access to natural resources (land) is also recognized internationally, as can be seen in the ILO (International Labor Organization) Convention No. 169 concerning indigenous people and customary law people in independent States which came into force on 5 September 1991 stipulating that: the government is obliged to respect the culture and spiritual values of indigenous people who are held up in their relationship to the land they occupy or use (Ismi, 2016).

Law No. 41 of 1999 on Forestry in Chapter IX on customary law communities in Article 67 
paragraph (1) states; The people of customary law insofar as they still exist and are acknowledged to be entitled to:

1. Collect forest products to meet the daily needs of the community concerned;

2. Carry out forest management activities under applicable customary law and not contradicting the law; and

3. Gain empowerment in order to improve welfare.

Indigenous people in their participation in controlling and access to natural resource management, especially forests, according to the Draft Law on Indigenous Forests mentioned are entitled to:

1. Manage forests within their customary jurisdiction;

2. Practice local knowledge, technology, and wisdom in managing forests;

3. Obtain facilitation from the government and/or local government and NGOs in the context of its empowerment;

4. Obtain protection from the government and/or local government; and

5. Participate in forest management and forest oversight.

The customary law community recognized for its existence shall:

1. Maintain and protect the forest from damage;

2. Utilize the forest in accordance with its main function

3. Rehabilitate and reforest customary forests;

4. According to the customary forest utilization stage, pay the land tax and building on customary forest land.

However, customary forests as recognized by the Forestry Law are included into state forests within the territories of customary law people. Yet, the customary law community right to the forest will be recognized as long as the fact remains and with its existence is permitted to:

1. Collect forest products to meet the daily needs of the indigenous people concerned;

2. Conduct forest management activities under customary law applicable and not contrary to law; and

3. Get empowerment in order to improve welfare.

However the provisions of the Act No. 41 of 1999 on Forestry hereinafter by the Constitutional Court Decision No. 35/PUU-X/2012 annulled several articles contained in the Act, among others Article 1 point 6 stating that customary forest is a State forest stated by the Constitutional Court that customary forests are forests belonging to indigenous people and not state forests.

Furthermore, in the framework of the Agrarian Reform, the legal policy on the regulation of customary rights is set forth in the MPR Decree No.IX/MPR/2001 on Agrarian Reform and Natural Resource Management. Article 6 determines the recognition of customary rights, among others, as follows:

1. Paragraph (1) on the customary rights of customary law communities on land, water, vegetation, and animals in their areas which are the source of their livelihoods that are in fact still in progress, recognized, respected, and protected in accordance with the dynamics of the development of customary law people, national and State interest, and the principle of the Unitary State of the Republic of Indonesia;

2. Paragraph (2) on the recognition of customary rights as referred to in paragraph (1) that may be confirmed by legislation based on certain criteria and research results involving the relevant customary law community, related institution, academician, and NGO.

The legislation in question is in the form of Regional Regulation of Regency/Municipality if the territory of customary rights is located in the Regency/City area, provincial Regulation if the customary right is in two districts or cities or more, and Presidential Decree if the customary right is in two or more Provinces;

3. Paragraph (3) on the criteria of the customary rights which are still referred to in paragraph

(2) includes the following elements:

a) Customary law people;

b) The territories in which customary land rights take place;

c) Relationships, interconnections, and dependence of customary law people with the land; 
d) The authority to regulate collectively the utilization of land, waters, plants and animals in the territory of the legal community under customary law.

Law No. 6 of 2014 on Villages clearly recognizes the existence of customary rights as follows:

1. Article 96 determines: Government, Provincial Governments, and Regency/Municipal Governments undertake the structuring of customary law community association to be determined as Indigenous Village.

2. Article 97 determines:

a) Determination of Indigenous Villages as referred to in Article 96 meets the following requirements: a. The association of customary law people and their traditional rights are still alive, whether they are territorial, genealogical or functional; $b$. The association of customary law people and their traditional rights is seen based on the development of society; and $c$. The association of customary law people together with their traditional rights are in accordance with the principle of the Unitary State of the Republic of Indonesia.

b) Association of customary law community and its traditional right as referred to in paragraph (1) letter a shall have territory and at least fulfill one or a combination of elements of: a. communities whose citizens have shared feelings within the group; $b$. customary government institutions; c. property and/or customary objects; and/or $d$. the device of customary law norms.

c) Customary law community association and their traditional right as referred to in paragraph (1) letter $b$ shall be considered in accordance with the development of the society if: a. its existence has been acknowledged under the existing law as a reflection of the development of values considered ideal in today's society, both general and sector laws; and $b$. the substance of the traditional right is recognized and respected by the citizens of the unity of the community concerned and the wider society and not contrary to human rights.

d) A customary law community association together with their traditional rights as referred to in paragraph (1) letter $c$ is in accordance with the principle of the Unitary State of the Republic of Indonesia if such customary law society does not bother the existence of the Unitary State of the Republic of Indonesia as a political unity and legal entity in which: a. it does not threaten the sovereignty and integrity of the Unitary State of the Republic of Indonesia; and b. the substance of customary law norms is appropriate and not contrary to the provisions of the laws and regulations.

Regulation of the Minister of Agrarian Affairs/Head of National Land Affairs Bureau no. 5 of 1999 concerning the Guidance on the Settlement of Problems of Indigenous People Customary Rights (known as Permeneg Agraria No. 5 Year 1999).

1. Article 1 stipulates that: Customary land is a plot of land on which there is customary right of a certain customary law community. Meanwhile, customary law people are a group of people bound by their customary legal order as citizens with a legal partnership because of the similarity of residence or on the basis of descent.

2. Article 5 determines: Regional Government is the party authorized to determine and grant recognition of customary rights in their respective areas through regional regulations.

4.2 The implementation of the recognition and reinforcement of the existence of customary law community associations and their rights by the central and regional governments

The 1945 Constitution, MPR Decree No. IX/MPR/2001, and various laws and regulations have regulated and clearly and firmly acknowledged the existence of customary law community associations and their rights in the territory of the legal alliance. The association of customary law community and their rights are still acknowledged as long as it exists, which means that the association of customary law communities must meet the requirements as determined by the laws. Either the 1945 Constitution, MPR Decree No. IX/MPR/2001 or various laws and regulations delegates to regional governments to acknowledge and strengthen Local Regulations.

In West Nusa Tenggara region there are several areas of customary law associations that 
control a certain territory and have certain assets that are managed and used together continuously. The association of customary law communities fulfills the criteria as established by the applicable laws and regulations, which are: 1 . customary law community associations, 2 . rules governing laws, 3. certain jurisdictions, and 4. continuous joint management. For instance, in Lombok Island there is customary land named "Tanah Paer" and "Tanah Pauman". The lands are controlled and managed jointly by members of the customary law community (Arba, 2013).

In North Lombok, Bayan District, there are some villages that still maintain their customary law in the framework of forest protection, including Bayan village and Mandala village. In these two villages, until now customary institutions and local wisdom values still exist. The customary law community of Bayan village in maintaining and protecting their customary forest area constitutes an institution and rule of law that stems from local wisdom values that must be obeyed by the customary law community and must also be obeyed by members of other customary law communities. Customary law created by the indigenous community of Bayan known as Awig-Awig (Arba, 2017).

In Bayan village, customary law community associations and their customary territories are only reinforced by Village Regulation No. 1 of 2006 on the Awig-Awig of Customary Forest of Bayan Village. In fact, until now the customary land and customary forest rights have not obtained legal recognition and guarantee from local government in the form of Local Regulation.

\section{Conclusion and Recommendations}

\subsection{Conclusion}

Legal arrangements on the recognition and reinforcement of the existence of customary law community associations and their rights in the 1945 Constitution, MPR Decree No.IX/MPR/2001, ILO Convention no. 169, the Laws, and various laws and regulations have clearly and unambiguously stated the existence of customary law community associations and their rights in the territory of the legal association.

The implementation of the recognition and reinforcement of the existence of customary law community associations and their rights by the Constitution and the laws and regulations, government regulations, and ministerial regulations shall be carried out under Regional Regulations. However, until now the provincial, district, and municipal governments in the province of West Nusa Tenggara have not had the political will to enact Local Regulations on the recognition and reinforcement of the existence of customary law community associations and their rights.

\subsection{Recommendations}

Based on the above facts, the authors recommend:

a. Considering the existence of customary community associations in the province of West Nusa Tenggara which is still in accordance with the requirements and criteria determined by the regulations of the legislation, the regional government must immediately establish a Regional Regulation on the recognition and reinforcement of the existence of customary law community associations and their rights.

b. Local governments should cooperate with universities to conduct field studies on the existence of customary law community associations and their rights as well as to design academic manuscripts and draft local regulations.

\section{References}

Arba. (2015). Hukum Agraria Indonesia. Sinar Grafika. Jakarta.

Arba. (2017). Eksistensi Pranata Lokal dalam Pengelolaan Hutan Adat pada Persekutuan Masyarakat Hukum Adat di Desa Bayan Kabupaten Lombok Utara. Research Result. 2017: 21.

Arba. (2013). Eksistensi Hak Ulayat Menurut Hukum Positif Indonesia. Paper presented at Forum Group Discussion in cooperation of DPR RI and Faculty of Law of Universitas Mataram. 
Bakri, M. (2007). Hak Menguasai Tanah Oleh Negara, (Paradigma Baru Untuk Reformasi Agraria). Citra Media. Yogyakarta.

Harsono, B. (2002). Menuju Penyempurnaan Hukum Tanah Nasional, dalam Hubungannya dengan TAP MPR RI IX/MPR/2001. Universitas Trisakti. Jakarta.

Ismi, H. (2016). Pengakuan dan Perlindungan Hukum Hak Masyarakat Adat Atas Tanah Ulayat dalam Upaya Pembaharuan Hukum Nasional. Jurnal IImu Hukum. Vol. 3 No. 1, May 20.

Soemardjono, M.S.W. (2001). Kebijakan Pertanahan antara Regulasi dan Implementasiny. Kompas. Jakarta.

Soemardjono, M.S.W. (2008). Tanah dalam Perspektif Hak Ekonomi, Sosial dan Budaya. Kompas, Jakarta, 2008.

Soekanto, S. (1984). Pengantar Penelitian Hukum. Universitas Indonesia Pers. Jakarta 